\title{
MOTOR ACTIVITY AND THE RESPIRATORY SYSTEM OF HIGH SCHOOL STUDENTS DURING THE CORONAVIRUS PANDEMIC
}

\section{Iryna Stepanova ${ }^{1}$ Taras Dutko ${ }^{2}$}

DOI: https://doi.org/10.30525/978-9934-26-076-6-7

Introduction. Regular physical activity is important for young people's health. However, people have trouble maintaining their physical activity in Ukraine and across the world as a result of acute quarantine measures. Due to the outbreak of a new, dangerous coronavirus (COVID-19) desease, people across the world have had a disruption in their common life and have found themselves unable to maintain their normal physical activity patterns. While a student's physical activity level should be at least 8-12 hours per week, online learning, social distancing, and lockdown have dramatically decreased it [4].

The COVID-19 pandemic has become a new challenge for the world and Ukraine. The rapid spread of coronavirus has forced all scientists to seek methods and means of disease protection and prevention, including physical culture and sports [6].

The coronavirus pandemic has been affecting teachers and students because the stress incrementally affects the human body, thus reducing its physical and psychological activity. Many studies show that lack of sufficient motor activity causes various physical and mental health problems [5, p. 25].

In today's situation, exercise can help maintain students' physical and mental health, whereas physical education teachers take on the role of an organizer of students' active physical activity outside of online learning [2].

The purpose of the article is to study and measure the fitness and motor activity of high school children during the coronavirus pandemic.

Research methods. Literature review; anthropometric methods; physiological methods; methods of evaluating physical health; chronometry method; statistical mathematics methods.

Study selection. The study involves students of 10-11 grades of I.S. Obdula Mezhyrytsky Lyceum of Pavlohrad Raion, Dnipropetrovsk region for the duration of the quarantine period from March 2020 to May 2020.

Study. Physical activity and exercise is the most important factor of a healthy lifestyle and good health in any age. The physical, mental, and social

\footnotetext{
${ }^{1}$ Prydniprovska State Academy of Physical Culture and Sports, Ukraine

${ }^{2}$ Dnipro National University of Railway Transport

named after Academician V. Lazaryan, Ukraine
} 
health of high school students is significantly influenced by specially organized motor activity pivoting on the conditions of the educational process and afterschool activities, especially during the quarantine. Quarantine measures during the COVID-19 pandemic have limited motor activity for billions of people around the world in an attempt to minimize spread [4; 5, p. 47; 6].

To measure motor activity, we used a method developed at Framingham State University [1, p.119]. Table 1 shows the results of the study.

Table 1

Distribution of time spent on different levels of physical activity of high school students per day, min

\begin{tabular}{|c|c|c|c|c|c|}
\hline \multirow{3}{*}{ 窇 } & \multicolumn{5}{|c|}{ Physical activity levels } \\
\hline & Basic & Sedentary & Small & Medium & High \\
\hline & $\bar{x} \pm S$ & $\bar{x} \pm S$ & $\bar{x} \pm S$ & $\bar{x}+S$ & $\bar{x} \pm S$ \\
\hline Males & $548,9 \pm 33,0$ & $287,2 \pm 31,4$ & $407,0 \pm 29,5$ & $159,9 \pm 21,9$ & $36,8 \pm 7,3$ \\
\hline Females & $691,8 \pm 35,5$ & $233,7 \pm 35,3$ & $420,1 \pm 22,3$ & $88,6 \pm 36,3$ & $5,3 \pm 12,6$ \\
\hline
\end{tabular}

The analysis of quantitative indicators of motor activity presented in Table 1 reveals that the male and female students spend the most time while having basic motor activity.

The students have long stretches of low-level physical activity due to learing online and preparing for college.

The sedentary level also takes much time in both male and female students due to social media, computer games, and TV watching.

The medium level of physical activity is associated with household chores and strolling outside.

The students have very little time for high-level physical activity due to strict quarantine measures and lockdown. As response to the outbreak of COVID-19, the students have changed their common habits and physical activity patterns.

(Lack of) physical activity acts as a reliable marker and predictor of health status. Our data on motor activity of the students indicate a need to introduce exercise in their daily routine outside of online learning hours during the quarantine.

Health is an essential component for high academic and work performance and harmonious well-being. Health is not simply defined as just the absence of disease or infirmity, but also as a state of complete social, physical and mental well-being. 
The assessment of physical health was carried out according to the method of G. L. Apanasenko (Table 2) [1, p. 156]. Sum scores of all the five indicators assess the physical health of the participants.

The proposed assessment system makes it possible to identify those students who need healthcare measures and prevention measures, as well as those who may be having symptoms of pre-pathological or pathological conditions.

Table 2

Physical health level of high school stidents, \%

\begin{tabular}{|c|c|c|c|c|c|c|}
\hline \multirow{2}{*}{ Gender } & \multirow{2}{*}{} & \multicolumn{5}{|c|}{ Levels of manifestation } \\
\cline { 4 - 7 } & & low & $\begin{array}{c}\text { below } \\
\text { average }\end{array}$ & average & $\begin{array}{c}\text { above } \\
\text { average }\end{array}$ & high \\
\hline males & 18 & 16,8 & 50,4 & 22,4 & 11,2 & - \\
\hline females & 18 & 28,0 & 50,4 & 16,8 & - & - \\
\hline
\end{tabular}

Most high school children have below average physical health $(50.4 \%$ of males and $50.4 \%$ of females), $16.8 \%$ of males and $28.0 \%$ of females have low-level physical health, $22.4 \%$ of males and $16.8 \%$ of females have average physical health and only $11.2 \%$ of males have above average health. There are no females with above average and high levels of physical health in the study. The findings suggest parents, teachers and doctors pay close attention to students' fitness and exercise.

The condition of one's respiratory system is one of the indicators that largely determine motor activity during the COVID-19 pandemic confinements (Table 3) [1, p. 48].

The analysis of respiratory indicators of the young people shows that vital lung capacity (VC) is $3077,0 \pm 286,4 \mathrm{ml}$, which is below normal pulmonary function values. Shtange and Genchi's test results are well below normal pulmonary function values.

Table 3

Respiratory indicators for high school students $(n=36)$

\begin{tabular}{|c|c|c|c|c|}
\hline \multirow{2}{*}{ Indicators } & \multicolumn{2}{|c|}{ Males $(n=18)$} & \multicolumn{2}{|c|}{ Females $(n=18)$} \\
\hline & $x$ & $S$ & $x$ & $S$ \\
\hline $\mathrm{VC}, \mathrm{ml}$ & 3077,0 & 286,4 & 2307,5 & 218,5 \\
\hline Shtange test, s & 43,15 & 3,75 & 38,9 & 4,15 \\
\hline Genchi test, s & 21,9 & 3,09 & 20,9 & 2,65 \\
\hline \multicolumn{5}{|l|}{ Orthostatic test, s } \\
\hline lying & 65,3 & 4,12 & 66,3 & 5,32 \\
\hline standing & 78,4 & 7,56 & 80,5 & 7,10 \\
\hline difference & 13,1 & 3,57 & 14,2 & 2,04 \\
\hline
\end{tabular}


In the females, vital lung capacity is below normal and $\mathrm{VC}$ is $2307.5 \pm 218.5 \mathrm{ml}$. Shtange and Genchi's test results for the females are also below normal pulmonary function values.

The cardiovascular system provides the link between pulmonary ventilation and oxygen usage when the body adapts to the stress of new levels of physical activity. However, the participants have low-level physical activity in their day-to-day living. Yet blood circulation is one of the most important functions in the body and directly impacts work and academic performance.

Interpreting the orthostatic test results of the high school students, the following data was collected: at supine position, heart rate is 66.3 beats/min in females and 65.3 beats/min in males, upright 80.5 beats/min in females and 78.4 beats/min in males; the difference between heart rate at supine position and upright is 14.2 beats/min in females and 13.1 beats/min in males. No meaningful difference was recorded in males and females. The test results correspond to the physical development of an untrained person (Table 3).

Conclusion. The study found that the results of the pulmonary function tests for high school students are below normal pulmonary function values whereas physical health levels are below average. Quarantine measures and lockdown have restricted outdoor physical activity of students in an attempt to minimize spread. Therefore, it is necessary to get high school students have motor activity outside of online learning hours during the quarantine period to improve their immune response to the coronavirus.

\section{References:}

1. Krutsevich T.Yu., Vorob'ev M.I. (2005) Kontrol' v fizicheskom vospitanii detey, podrostkov i yunoshey [Control in the physical education of children, adolescents and youth]. Kyiv: NUFViSU. (in Russian)

2. Myzdrenko O.M., Zadan A.V. (2017) Ozdorovci tehnologiji u profilaktyci zahvorjuvan' dyhal'noji systemy skoljariv. Molodyj vchenij, no. 9.1(49.1), pp. 119-123.

3. Mihejenko O.I. (2020) Shhodennyk zdorov'ja [Health diary]. Universytets'ka knyha. (in Ukrainian)

4. Orfin A., Mazepa M. (2020) Fizychna aktyvnistj pid chas pandemiji COVID-19 [Physical activity during a pandemic COVID-19]. Proceedings of the IV Mizhnar. nauk.prakt. Internet-konf. (10 June, 2020). Lutsk: Shidnojevrop. nac. un-t im. Lesi Ukrainky.

5. Stepanova I., Ben'ko O., Hryhorovs'kyj M. (2020) Orhanizacija samostijnyh zanjatj fizychnoju kuljturoju licejistiv $\mathrm{v}$ umovax koronavirusnoji epidemiji. III Vseukrajins'kyj vidkrytyj naukovo-praktyčnyj onlajn-forum «Innovacijni transformaciji v sucasnij osviti: vyklyky, realiji, stratehiji». (Ukraine, Kyiv, 25-26 November 2020), pp. 33-36.

6. Snyt I. (2020) Formy fizychnoji aktyvnosti, scho v umovah epidemiji spryjajut' usunennju hipokineziji skoljariv. Fizychna aktyvnist' i jakist' zhyttja ljudyn. zb. tez dop. IV Mizhnar. nauk.-prakt. Internet-konf. (10 June, 2020). Lutsk: Shidnojevrop. nac. un-t im. Lesi Ukrainky. 